\title{
PRODUKSI KITOSAN DARI CANGKANG RAJUNGAN (Portunus sp.) PADA SUHU RUANG
}

\author{
Dessy Atika Natalia ${ }^{1,4 *}$, Niken Dharmayanti ${ }^{2}$, Fera Roswita Dewi ${ }^{3}$ \\ ${ }^{1}$ Program Studi Pemanfaatan Sumberdaya Perikanan, Peminatan Industri Pengolahan Hasil Perikanan \\ ${ }^{2}$ Pascasarjana, Politeknik AUP Jakarta, Jalan AUP No.1 Pasar Minggu-Jakarta Selatan \\ ${ }^{3}$ Peneliti BBRPPB Kelautan dan Perikanan, Jalan KS Tubun, Petamburan VI, Slipi, Jakarta Pusat \\ ${ }^{4}$ Politeknik Kelautan dan Perikanan Bitung, Jalan Tandurusa Aertembaga Dua Kota Bitung-Sulut
}

Diterima: 23 Juli 2021/Disetujui: 24 September 2021

*Korespondensi: dessyan2112@gmail.com

Cara sitasi: Natalia DA, Dharmayanti N, Dewi FR. 2021. Produksi kitosan dari cangkang rajungan (Portunus sp.) pada suhu ruang. Jurnal Pengolahan Hasil Perikanan Indonesia. 24(3): 301-309.

\begin{abstract}
Abstrak
Limbah cangkang rajungan dapat dimanfaatkan menjadi kitosan yang dihasilkan dari proses deasetilasi kitin dengan basa kuat serta menggunakan suhu tinggi. Penggunaan suhu tinggi selama proses berisiko tinggi, sehingga produksi kitosan tanpa tahap pemanasan dapat menjadi solusi untuk mengurangi risiko kecelakaan. Tujuan penelitian ini adalah memproduksi kitosan dari cangkang rajungan pada suhu ruang tanpa adanya pemanasan. Kitosan dibuat melalui tahapan- tahapan berikut yaitu deproteinasi, demineralisasi, dan deasetilasi. Proses pembuatan kitosan dilakukan sebanyak tiga kali ulangan pada waktu yang berbeda dengan metode yang sama dan terukur. Kitosan yang dihasilkan kemudian dikarakterisasi. Kitosan yang dihasilkan memiliki warna putih kekuningan, berbentuk serpihan dan tidak berbau, dengan kadar air 11,25-12,93\%, kadar abu 1,62-1,75\%, kadar nitrogen 5,12-5,45\%, kadar lemak 0,25-0,49\%, viskositas 37,50-38,33 cPs, kelarutan 99,50-99,57\% dan derajat deasetilasi 57,64\%. Dapat disimpulkan bahwa kitosan dapat dibuat tanpa menggunakan proses pemanasan dan memenuhi standar mutu kitosan komersial kecuali nilai derajat deasetilasi rendah. Pembuatan kitosan tanpa pemanasan diharapkan dapat diterapkan pada miniplant rajungan sehingga dapat memberi nilai tambah untuk cangkang rajungan.
\end{abstract}

Kata kunci: derajat deasetilasi, kitosan, cangkang rajungan, tanpa pemanasan, suhu ruang

The Production of Chitosan from Crab Shell (Portunus sp.) at Room Temperature

\begin{abstract}
Crab shell (Portunus sp.) can be used as a raw material for chitosan which obtained by hydrolyzing chitin by using strong alkali and high temperature. The use of high temperature during the process, producing chitosan without any thermal stage can be a possible solution to reduce hazard. The study aims to produce chitosan from crab shells using non thermal method. Chitosan was made through these stages: deproteination, demineralization and deacetylation, proses pembuatan kitosan dilakukan sebanyak tiga kali ulangan pada waktu yang berbeda dengan metode yang sama dan terukur.The yielded chitosan then characterized. The results showed that the chitosan has yellowish white color, in flakes form and odorless with moisture, ash, nitrogen, lipid, viscosity, solubility, and degree of deacetylation 11.25-12.93\%, 1.62$1.75 \%, 5.12-5.45 \%$, lipid $0.25-0.49 \%, 37.50-38.33$ cPs, $99.55-99.57 \%$ and $57.64 \%$ respectively. In conclusion chitosan can be made with non thermal method met the commercial standards of chitosan except for the low deacetylation. Processing chitosan with non thermal methode can be applied at small crab miniplant, thus the crab shells has more economical value.
\end{abstract}

Keyword: chitosan, degree of deacetylation, non thermal, crab, room temperature 


\section{PENDAHULUAN}

Permintaan rajungan meningkat setiap tahun sehingga menambah volume limbah cangkang rajungan, karena dalam pengolahannya hanya memanfaatkan daging rajungan segar, daging beku ataupun daging rajungan yang telah diolah dalam kaleng. Proses pengambilan daging rajungan meninggalkan limbah cangkang atau kulit keras dengan jumlah yang sangat banyak mencapai 40 sampai dengan 60 persen dari total berat rajungan (Rochima 2014). Limbah dari cangkang rajungan memiliki kandungan kimia yang bermanfaat di antaranya; $30-40 \%$ protein; $30-50 \%$ mineral $\left(\mathrm{CaCO}_{3}\right)$; dan 20 30\% kitin (Srijanto 2003 dalam Purnavita 2007). Kandungan kimia cangkang rajungan hasil buangan ternyata dapat dimanfaatkan sebagai bahan baku kitosan.

Suptijah (2006) menyatakan kitosan merupakan hasil deasetilasi kitin yang memiliki rumus D-Glukosamin, yaitu polimer kationik serta memiliki jumlah monomer sekitar 2000-3000, tidak beracun dengan $\mathrm{LD} \neg 50=16 \mathrm{~g} / \mathrm{kg}$ BB dengan berat molekul sekitar 800 Kda. Savant et al. (2000) dalam Chamidah (2019) menyatakan bahwa kitosan terbentuk apabila beberapa gugus asetil dari kitin dihilangkan dengan menggunakan metode deasetilasi parsial. Kitosan memiliki reaktivitas yang lebih tinggi dibandingkan kitin sebab terdiri dari gugus amina bebas dan merupakan nukleofil kuat, sehingga kitosan lebih banyak digunakan pada dunia industri.

Kitosan masih memiliki kekurangan, yaitu sukar larut dalam air ( $\mathrm{pH}$ netral), sebab kitosan memiliki rantai yang panjang (Tanasale 2016). Proses pembuatan kitosan biasanya terdiri dari tiga tahap yaitu deproteinasi, demineralisasi, dan deasetilasi. Umumnya deasetilasi kitosan dilakukan dengan menggunakan pemanasan (suhu tinggi $>70^{\circ} \mathrm{C}$ ), hal ini tergolong berbahaya bagi keamanan, karena suhu panas berisiko tinggi dan dapat menyebabkan kebakaran. Penelitian kitosan masih terus dilakukan untuk mencari derajat deasetilasi yang tinggi agar pemanfaatannya optimal, namun hampir setiap penelitian kitosan masih menggunakan pemanasan dan peralatan khusus sehingga tidak mudah diaplikasikan pada area miniplant rajungan yang memiliki keterbatasan peralatan.

Purnavita (2007) melakukan penelitian kitosan dari cangkang rajungan dengan proses deproteinasi menggunakan suhu $80^{\circ} \mathrm{C} \quad 1: 6$ (b/v) $\mathrm{NaOH} 2 \mathrm{~N}$ selama 1 jam, demineralisasi menggunakan asamklorida $1,5 \mathrm{~N} 1: 2(\mathrm{~b} / \mathrm{v})$ suhu kamar, deasetilasi $\mathrm{NaOH} 50 \%$ 1:20 (b/v) suhu $90^{\circ} \mathrm{C} 2$ jam menghasilkan derajat deasetilasi 79,65\%; Fawzya et al. (2008) kitosan dari limbah rajungan melalui tahap deproteinasi dilakukan selama 2 jam dengan $\mathrm{NaOH}$ teknis $3,5 \%$ pada suhu $70^{\circ} \mathrm{C}$, demineralisasi selama 1 jam pada suhu kamar menggunakan $\mathrm{HCl}$ teknis $15 \%$, deasetilasi menggunakan $\mathrm{NaOH}$ $60 \%$ suhu $27^{\circ} \mathrm{C}$ selama 5 hari menghasilkan derajat deasetilasi 58,49\%; Belangi (2018) dari kulit udang tahap demineralisasi dilakukan pada suhu $90^{\circ} \mathrm{C}$ selama 1 jam memakai HCL 1 $\mathrm{N}, 1: 7$, deasetilasi dilakukan pada suhu $140^{\circ} \mathrm{C}$ selama 2 jam menggunakan $\mathrm{NaOH} 50 \%$ 1:10 (b/v); Sudianto (2020) dari kulit udang tahap demineralisasi pada suhu $90^{\circ} \mathrm{C}$ dengan $\mathrm{HCl}$ $1,5 \mathrm{~N}$ 1:9, deasetilasi dengan $\mathrm{NaOH} 50 \%$ 1:10 suhu $130^{\circ} \mathrm{C}-140^{\circ} \mathrm{C}$ menghasilkan nilai derajat deasetilasi 79,1\%. Sebagian besar penelitian kitosan menggunakan pemanasan, sehingga perlu dilakukan produksi kitosan tanpa adanya pemanasan dalam setiap tahapan prosesnya untuk mengurangi risiko kebakaran serta lebih aman dan mudah untuk dilakukan karena tidak memerlukan peralatan khusus, sehingga mudah dilakukan pada area miniplant rajungan.

Penelitian ini bertujuan memanfaatkan limbah cangkang rajungan untuk menghasilkan kitosan yang memiliki karakteristik kitosan komersial yang dilakukan pada suhu ruang tanpa memerlukan pemanasan atau alat khusus dalam proses produksinya, sehingga dapat diterapkan oleh masyarakat luas khususnya miniplant rajungan dan memberikan nilai tambah pada cangkang rajungan yang selama ini belum termanfaatkan dengan optimal.

\section{BAHAN DAN METODE Bahan dan Alat}

Bahan yang dipakai dalam pembuatan kitosan yaitu limbah cangkang rajungan dari miniplant rajungan Karangantu, Serang- 
Banten. Bahan kimia yang dipakai ialah $\mathrm{NaOH}$ teknis (Rofa CAS 1310-73-2), HCl teknis 32\% (Rofa, RLC2.0068.0500), asam asetat glasial (Merck, 1.00063.2500) dan akuades.

\section{Metode}

Metode penelitian ini berdasarkan metode dalam Fawzya et al. (2008) yang dimodifikasi. Limbah cangkang rajungan dibersihkan dari sisa daging yang menempel dan direndam dalam larutan $\mathrm{NaOH} 2 \%$ $1: 20 \quad(\mathrm{~b} / \mathrm{v})$ semalaman $( \pm 12$ jam $)$ untuk menghilangkan sisa daging atau kotoran yang menempel pada cangkang rajungan, kemudian dicuci dengan air mengalir sampai $\mathrm{pH}$ netral dan dicek menggunakan kertas $\mathrm{pH}$ universal. Cangkang rajungan dijemur di bawah sinar matahari (suhu $37-40{ }^{\circ} \mathrm{C}$ ) sampai cangkang kering. Cangkang rajungan yang telah kering ditimbang sebanyak $1.000 \mathrm{~g}$ sebagai berat awal dari bahan baku cangkang rajungan sebelum masuk ke dalam tahapan proses pembuatan kitosan.

Proses pembuatan kitosan dimulai dengan penghilangan zat protein dari cangkang rajungan atau deproteinasi yang mengacu pada metode Fawzya et al. (2008) dengan sedikit modifikasi pada konsentrasi $\mathrm{NaOH}$, suhu, dan waktu deproteinasi. Deproteinasi dilakukan dengan menggunakan $\mathrm{NaOH} \quad 4 \% \quad 1: 10 \quad(\mathrm{~b} / \mathrm{v})$ didiamkan selama 24 jam pada suhu ruang $\left(30-32{ }^{\circ} \mathrm{C}\right)$ tanpa pemanasan sambil dilakukan pengadukan manual dengan sendok kayu secara berkala. Tahap deproteinasi kemudian dilanjutkan dengan proses netralisasi menggunakan air mengalir. Netralisasi dilakukan untuk menghilangkan sifat basa yang masih ada pada cangkang rajungan sampai $\mathrm{pH}$ netral. Cangkang rajungan hasil proses deproteinasi yang telah memiliki $\mathrm{pH}$ netral kemudian dijemur dibawah sinar matahari selama \pm 12 jam atau sampai kering.

Cangkang rajungan yang telah kering dilanjutkan dengan tahap penghilangan zat mineral atau demineralisasi yang memodifikasi dari penelitian Fawzya et al. (2008) dengan konsentrasi $\mathrm{HCl}$, waktu dan suhu yang berbeda. Demineralisasi pada penelitian ini menggunakan larutan asam klorida $(\mathrm{HCl})$ $18 \%$ dengan perbandingan $1: 6(\mathrm{~b} / \mathrm{v})$ dari berat awal bahan baku. Proses demineralisasi dilakukan pada suhu ruang $\left(30-32^{\circ} \mathrm{C}\right)$ selama satu hari (24 jam) disertai pengadukan manual secara berkala, untuk memaksimalkan proses pelepasan zat-zat mineral yang masih ada pada cangkang rajungan. Cangkang rajungan yang telah direndam dalam larutan $\mathrm{HCl}$, kemudian dinetralisasi kembali dengan air mengalir untuk menghilangkan sifat asam pada cangkang rajungan dengan cara mengukur $\mathrm{pH}$ air cucian hingga netral menggunakan kertas $\mathrm{pH}$ universal, dilanjutkan penjemuran dibawah sinar matahari (suhu $37-40{ }^{\circ} \mathrm{C}$ ) sampai kering. Cangkang rajungan yang telah kering kemudian ditimbang agar diketahui rendemen kitin yang dihasilkan. Cangkang rajungan yang telah melalui tahap deproteinasi dan demineralisasi disebut kitin.

Kitin yang didapat selanjutnya masuk ke tahap deasetilasi. Tahap deasetilasi pada penelitianinimengacupada Fawzya et al.(2008) yang telah dimodifikasi dengan penambahan $\mathrm{NaOH} 70 \%$ 1:5 (b/v), yang dilakukan pada suhu ruang $\left(30-32^{\circ} \mathrm{C}\right)$ dengan penambahan hari yaitu selama 7 hari, dengan pengadukan manual untuk mendapatkan kitosan dengan harapan memiliki derajat deasetilasi (DD) yang tinggi tanpa adanya pemanasan. Tahap deasetilasi selesai dilanjutkan dengan proses netralisasi dengan akuades sampai $\mathrm{pH}$ netral menggunakan kertas $\mathrm{pH}$ universal, penyaringan residu kitosan dengan kain saring ukuran 100 mesh kemudian dijemur kembali sampai benar- benar kering dibawah sinar matahari (suhu $37-40{ }^{\circ} \mathrm{C}$ ) dan dihitung kembali rendemen hasil proses deasetilasi. Proses pembuatan kitosan dilakukan sebanyak tiga kali ulangan pada waktu yang berbeda dengan metode yang sama dan terukur. Kitosan dikarakterisasi berdasarkan nilai rendemen, proksimat, viskositas, kelarutan dan juga derajat deasetilasinya, sedangkan penampakan kitosan diuji oleh 25 orang panelis tidak terlatih.

\section{Prosedur Kimia Rendemen (AOAC 2005)}

Nilai rendemen dari kitosan dihitung berdasarkan perbandingan antara berat kitosan yang didapat dengan berat cangkang rajungan pada awal proses. Perhitungan 
rendemen dilihat pada rumus di bawah ini:

Rendemen $=\frac{\text { berat kitosan yang dihasilkan }}{\text { berat cangkang rajungan }} \quad \mathrm{x} 100 \%$

\section{Proksimat}

Kadar air dihitung berdasarkan SNI 012354.2-2006, kadar abu SNI 01-2354.1-2006, nitrogen AOAC 2005.

\section{Derajat Deasetilasi}

Derajat deasetilasi ditentukan berdasarkan pada hasil FTIR kitosan dan dihitung berdasarkan rumus rumus Domzy dan Roberts (Gintu 2017) sebagai berikut:

Derajat deasetilasi $=100-\frac{\left[\mathrm{A}_{1655}\right]}{\left[\mathrm{A}_{3450}\right]} \times \frac{100}{1,33}$

Keterangan:

$A_{1655}:$ Nilai absorbansi gugus amida sekitar $1655 \mathrm{~cm}^{-1}$

$\mathrm{A}_{3450}:$ Nilai absorbansi gugus hidroksil sekitar $3450 \mathrm{~cm}^{-1}$

1,33:Rasio gugus amida $\left(\mathrm{A}_{1655}\right) /$ gugus hidroksil $\left(\mathrm{A}_{3450}\right)$ untuk kitosan yang terdeasetilasi $100 \%$

\section{Kelarutan}

Kelarutan kitosan diuji dengan memasukkan 1 g kitosan dan dilarutkan dalam asam asetat $2 \%$ sebanyak $100 \mathrm{~mL}$ (1:100 b/v) (Lalenoh 2018). Larutan kitosan disaring dengan kertas saring dan dikeringkan. Kertas saring yang telah kering ditimbang sampai berat konstan.

Ketidaklarutan $(\%)=\frac{\text { berat akhir }}{\text { berat awal }} \times 100 \%$

Kelarutan(\%)=100\%-ketidaklarutan

\section{Analisis Data}

Data yang dihasilkan dianalisis dengan statistik menggunakan One Way Anova (SPSS versi 23, IBM) yang ditampilkan dengan bentuk tabel dan deskriptif.

\section{HASIL DAN PEMBAHASAN Rajungan} Analisis Proksimat Cangkang

Cangkang rajungan sebagai bahan baku penelitian ini didapatkan dari Serang-Banten. Cangkang rajungan yang telah dibersihkan dianalisis terlebih dahulu untuk mengetahui kadar proksimatnya. Hasil uji proksimat terhadap cangkang rajungan dapat dilihat pada Table 1.

Table 1 Crab shell proximate test

\begin{tabular}{lr}
\hline Composition & Result (\%) \\
\hline Water & $5.23 \pm 0.21$ \\
Ash & $16.82 \pm 0,23$ \\
Protein & $9,01 \pm 0,24$ \\
Fat & $0,083 \pm 0,12$ \\
\hline
\end{tabular}

Nadia et al. (2018) melaporkan dalam penelitiannya cangkang rajungan memiliki nilai kadar air 8,55\%, kadar abu 60,83\%, dan kadar protein $11,20 \%$, sedangkan menurut hasil penelitian Sukma et al. (2014) dalam Nadia et al. (2018) cangkang rajungan menghasilkan nilai kadar air 8,10\%, kadar abu $25,58 \%$, dan kadar protein $13,19 \%$. Hasil uji proksimat dari beberapa penelitian di atas berbeda dengan apa yang dihasilkan pada penelitian ini, hal ini dimungkinkan karena lingkungan daerah hasil penangkapan rajungan yang berbeda dan juga proses pengujian dan juga pembuatannya yang berbeda.

\section{Karakteristik Kitosan}

Karakteristik kitosan penelitian ini berupa rendemen, warna, bau, bentuk, kadar proksimat, viskositas, derajat deasetilasi dan kelarutannya. Hasil karakteristik disajikan pada Table 2.

\section{Rendemen}

Nilai rendemen kitosan yang didapatkan pada penelitian ini sebesar $13,37 \%$. Setha (2019) pada penelitiannya menghasilkan kitosansebesar 5,12-5,63\%lebih kecil darinilai rendemen kitosan uji; Lalenoh (2018) 4,93\%; namun masih lebih rendah dibandingkan nilai rendemen Nadia et al. (2018) 17,39\%; Cahyono (2015) 14\%; Ariesta (2007) 23,13\%. Keberhasilan proses pembuatan kitosan dapat diukur dari nilai rendemen yang dihasilkan. Cahyono (2015) juga menyatakan bahwa efisien dan efektifnya suatu ekstraksi pada bahan baku dalam pembuatan kitosan terlihat dari nilai rendemennya. 
Table 2 Characterization of chitosan from crab shell

\begin{tabular}{lrrr}
\hline \multicolumn{1}{c}{ Parameter } & EFSA $2010^{\mathrm{a}}$ & SNI Chitosan $^{\mathrm{b}}$ & \multicolumn{1}{c}{ Result } \\
\hline Yield (\%) & - & - & $13.37 \pm 0.21$ \\
Colour & - & Light Brown to White & Yellowish White \\
Shape & - & - & Flakes \\
Odor & - & - & Odorless \\
Water (\%) & $\leq 10$ & $\leq 12$ & $11.25-12.93$ \\
Ash (\%) & $\leq 3$ & $\leq 5$ & $1.62-1.75$ \\
Nitrogen (\%) & $\leq 6$ & $\leq 5$ & $5.12-5.45$ \\
Lipid (\%) & $\leq 1$ & - & $0.25-0.49$ \\
Viscosity (cPs) & - & - & $37.50-38.33 \mathrm{cPs}$ \\
Degree of & $\geq 90$ & $\geq 75$ & 57.64 \\
Deacetylation (\%) & & & Fat \\
Fat & $0.083 \pm 0.12$ & Fat & \\
\hline
\end{tabular}

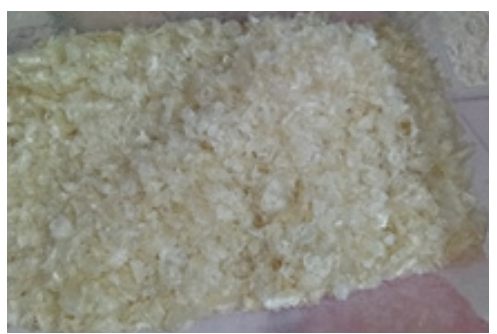

Figure 1 Chitosan from crab shell

No et al. (1989) dalam Setha et al. (2019) melaporkan bahwa rendahnya rendemen kitosan yang dihasilkan akibat dari tingginya konsentrasi $\mathrm{NaOH}$ yang dipakai pada tahap deasetilasi. Rendemen pada hasil penelitian ini cukup tinggi, karena saat proses deproteinasi, demineralisasi, dan deasetilasi baik kitin maupun kitosan tidak banyak hilang oleh pelarut pada saat pencucian (netralisasi). Proses netralisasi dengan akuades dilakukan dengan sangat hati-hati untuk menghindari penyusutan bobot kitin maupun kitosan.

\section{Warna, Bentuk, dan Bau}

Penelitian ini menghasilkan kitosan berwarna putih kekuningan, berbentuk serpihan dan tidak berbau. Ini dikarenakan pada saat netralisasi setelah tahap deproteinasi, demineralisasi serta deasetilasi dilakukan dengan baik sehingga zat kimia benar- benar hilang terbawa oleh air dan warna kitosan setelah dikeringkan menjadi putih kekuningan. Figure 1 memperlihatkan hasil kitosan uji.

Warna kitosan putih kekuningan diakibatkan adanya proses yang belum sempurna pada tahap deproteinasi, demineralisasi dan juga tahap deasetilasi, yang menyebabkan bahan organik tidak hilang sempurna dari kitosan, hal ini juga dikuatkan oleh Setha et al. (2019) yang melaporkan kitosan memiliki warna putih krem akibat depigmentasi yang belum sempurna pada tahap deasetilasi. $\mathrm{HCl}$ dan gula amino yang berinteraksi juga dapat menyebabkan komponen furfural berwarna cokelat akibat adanya reaksi enolisasi glikosil amino (Afridina 2011)

Kitosan dari penelitian ini memiliki kesamaan dengan hasil penelitian Suptijah et al. (1992) yaitu berwarna putih kekuningan dan berbentuk bubuk, lain halnya dengan hasil penelitian Cahyono (2015) yang memiliki warna kitosan putih kecokelatan. 


\section{Kadar Air}

Kadar air hasil penelitian berkisar 11,25$12,93 \%$ dengan hasil stastistik $p>0,05$ yang artinya tidak ada perbedaan nyata antara hasil uji kadar air dari proses pembuatan kitosan pertama, kedua dan ketiga. Nilai kadar air kitosan uji masih tinggi bila dibandingkan standar kitosan komersial yaitu $\leq 10 \%$. Hal ini diduga karenakan pada saat penjemuran kitosan hanya mengandalkan sinar matahari. Tingginya kadar air merupakan akibat dari proses pengeringan yang masih belum sempurna (Ariesta 2007).

Walke et al. (2014) sifat kitosan salah satunya ialah higroskopis dialam, sehingga dalam penyimpanan kitosan mampu menyerap uap air disekitarnya. Penyimpanan kitosan didalam toples kaca kedap udara akan lebih baik dalam menjaga supaya kadar airnya tidak bertambah.

\section{Kadar Abu}

Kadar abu kitosan hasil uji yaitu berkisar $1,62-1,75 \%$ dengan nilai $p>0,05$ dan tidak ada perbedaan nyata nilai kadar abu antara proses pertama, kedua dan ketiga. Kadar abu hasil uji sudah sesuai standar kadar abu kitosan komersial yaitu $\leq 2 \%$ (Suptijah 1992) dan $\leq 3 \%$ (EFSA 2010). Rendahnya kadar abu kitosan uji karena adanya tahap demineralisasi pada proses pembuatan kitosan. Kandungan mineral dihilangkan dengan bantuan larutan $\mathrm{HCl}$ yang mengikat mineral (Hartati 2002 dalam Lalenoh 2018). Pencucian yang baik pada tahap netralisasi juga berpengaruh terhadap nilai kadar abu, karena pada saat proses pencucian mineral yang terlepas terbuang bersama-sama dengan air (Angka dan Suhartono 2000).

\section{Kadar Nitrogen}

Kadar nitrogen menandakan keberhasilan akan tahapan proses deproteinasi pada saat pembuatan kitosan. Hong et al. (1989) juga menyatakan indikator proses deproteinasi ialah kadar total nitrogen yang tersisa. Kadar nitrogen kitosan uji berkisar 5,12\%-5,45\%, dengan nilai $p>0,05$ dan tidak ada pengaruh nyata antara kadar nitrogen proses pertama, kedua dan ketiga. Kadar nitrogen uji sudah sesuai dengan standar kitosan EFSA (2010) yaitu $\leq 6 \%$, namun sedikit lebih besar dari hasil penelitian Suptijah et al. (1992) $\leq 5 \%$. Nitrogen uji hasil penelitian masih sesuai standar menandakan proses deproteinasi pada penelitian ini cukup baik.

\section{Kadar Lemak}

Kitosan hasil uji memiliki nilai kadar lemak dengan kisaran 0,25-0,49\% dengan hasil uji statistik tidak berbeda nyata atau $p>0,05$ yang berarti nilai kadar lemak kitosan proses pertama, kedua dan ketiga telah homogen. Proses deproteinasi dengan larutan basa dan proses demineralisasi dengan larutan asam dapat memengaruhi nilai kadar lemak kitosan, sebab mampu mereduksi protein, mineral, lemak, dan bahan organik lainnya (Cahyono 2015). Nilai kadar lemak hasil uji tergolong rendah dan masih di bawah kadar air hasil penelitian Nazin (2005) yang berkisar 0,704,01\% dan Cahyono (2015) sebesar 3,13\%.

\section{Viskositas}

Nilai viskositas kitosan pada penelitian ini berkisar 37,50-38,33 cPs. Nilai viskositas kitosan proses pertama, kedua dan ketiga tidak berbeda nyata karena $p>0,05$. Nilai viskositas penelitian ini tergolong rendah karena masih $<200$ cPs menurut standar kitosan komersial dari Sutptijah et al. (1992). Rendahnya nilai viskositas kitosan diduga karena pengaruh tahap deasetilasi pada saat pembuatan kitosan. Nadia et al. (2018) menyatakan lamanya proses deasetilasi, serta konsentrasi $\mathrm{NaOH}$ yang tinggi akan menurunkan viskositas dan berat molekul.

Viskositas juga dipengaruhi oleh panjangnya rantai polimer, semakin panjang rantai polimer maka semakin tinggi nilai viskositas, sehingga untuk mendapatkan nilai viskositas yang rendah rantai polimer harus diputus menjadi rantai monomer. Pemutusan rantai polimer dipengaruhi oleh beberapa faktor seperti suhu, basa kuat, waktu, serta enzim yang pada tahap deasetilasi maupun karboksimetilasi (Rinaudo et al. 1992 dalam Fawzya et al. 2008). Viskositas yang rendah menandakan keberadaan rantai polimer sudah terputus sehingga terbentuk rantai yang lebih pendek (Fawzya et al. 2008). 


\section{Derajat Deasetilasi Kitosan}

Parameter mutu kitosan lainnya ialah nilai derajat deasetilasi yang ditentukan berdasarkan jumlah gugus asetil yang dapat dihilangkan pada tahap deasetilasi kitin menjadi kitosan. Konsentrasi $\mathrm{NaOH}$ yang tinggi dalam larutan mengakibatkan gugus fungsional amino $\left(-\mathrm{NH}_{3}+\right)$ yang mensubstitusi gugus asetil kitin di dalam larutan semakin aktif yang menyebabkan semakin baiknya proses deasetilasi, sehingga nilai derajat deasetilasi semakin tinggi (Rochima 2007).

Derajat deasetilasi kitosan ditentukan dengan metode garis dasar pada hasil FTIR kitosan (Bagheriet al.2009). Prinsip penentuan derajat deasetilasi adalah perbandingan nilai absorbansi amida dalam gugus asetil dan gugus hidroksil yaitu pada panjang gelombang $1655 \mathrm{~cm}^{-1}$ dan $3450 \mathrm{~cm}^{-1}$ (Yusharani 2019). Gugus fungsi $\mathrm{OH}$ ulur dan $\mathrm{NH}$ ulur pada penelitian ini terlihat pada puncak bilangan gelombang $3463 \mathrm{~cm}^{-1}$. Bilangan gelombang $2970 \mathrm{~cm}^{-1}$ memperlihatkan gugus fungsi $\mathrm{CH}$ ulur, dan bilangan gelombang $1646 \mathrm{~cm}^{-1}$ menunjukan gugus fungsi $\mathrm{C}=\mathrm{O}$ amida. Grafik Spektra FTIR kitosan penelitian ini sudah menunjukkan adanya pita serapan amida dan gugus hidroksil yang mencirikan kitosan pada umumnya. Figure 1 memperlihatkan grafik FTIR kitosan.

Nilai derajat deasetilasi pada penelitian ini dihitung menggunakan rumus Domzy dan Roberts (1995) yaitu sebesar 57,64\%. Derajat deasetilasi akan semakin tinggi bila suhu pemanasannya juga semakin tinggi dan waktu reaksinya semakin lama (Fadli et al. 2015). Hasil derajat deasetilasi pada kitosan masih rendah karena pada pembuatan kitosan tidak menggunakan suhu panas (suhu ruang 30-32 ${ }^{\circ} \mathrm{C}$ ), walaupun waktu yang digunakan pada proses deasetilasi cukup lama yaitu 7 hari.

Nilai DD kitosan pada penelitian yaitu $57,64 \%$ dan sudah dapat dikatakan kitosan. Azhar et al. dalam penelitiannya menyatakan kitosan dengan DD 40-100\% dapat disebut kitosan. Gintu et al. (2017) dalam penelitiannya menghasilkan DD sebesar 57,61\% yang juga dapat dikatakan kitosan. Kitosan dengan nilai DD rendah dapat dijadikan sebagai pemurni air limbah (Bastaman 1989 dalam Setha
2019), lain halnya pada penelitian Sofia et al. 2016 bahwa kitosan dengan nilai DD 46,92\%$59,38 \%$ dapat digunakan untuk pengemasan, maupun edible film.

\section{Kelarutan}

Kelarutan kitosan penelitian ini yaitu berkisar 99,55-99,57\% dengan nilai $p>0,05$ yang artinya tidakpengaruh nyata antara proses kitosan pertama, kedua dan ketiga. Kitosan hasil uji larut sempurna pada asam asetat $2 \%$ karena nilai kelarutan $>99 \%$, penelitan Gintu et al. (2017) dengan derajat deasetilasi 57, 6161\% juga melaporkan kelarutan sempurna $100 \%$ kitosan penelitiannya dalam asam asetat $1 \%$.

Kitosan hasil proses sudah memenuhi kelarutan kitosan yang dapat larut sempurna dalam asam encer, meskipun memiliki derajat deasetilasi $<70 \%$, berbeda dengan kitin yang tidak dapat larut pada asam encer. Asam encer seperti asam asetat, asam sitrat maupun asam format dapat melarutkan kitosan, namun kitosan dapat larut dalam air bila telah mengalami substitusi, semakin tinggi kelarutan maka nilai derajat deasetilasi juga akan meningkat, hal ini dipengaruhi oleh proses deasetilasi yang memotong gugus asetil kitin dan membentuk gugus amina, sehingga ion $\mathrm{H}+$ pada gugus amina menyebabkan kitosan cepat berikatan dengan air melalui ikatan hidrogen (Rochima 2007).

\section{KESIMPULAN}

Kitosan dapat dibuat dari limbah cangkang rajungan tanpa menggunakan pemanasan dan peralatan khusus dan sudah memenuhi standar mutu kitosan komersial kecuali nilai derajat deasetilasi yang masih $<70 \%$ serta dapat diterapkan pada miniplant rajungan.

Penelitian lebih lanjut terhadap pembuatan kitosan pada suhu ruang perlu dikembangkan agar mendapatkan nilai derajat deasetilasi yang optimal mendekati standar nilai derajat deasetilasi kitosan sesuai SNI, serta perlu dilakukan penelitian terhadap pengaplikasian kitosan dengan nilai derajat deasetilasi yang rendah. 


\section{UCAPAN TERIMA KASIH}

Penulis menyampaikan terima kasih atas beasiswa dan bantuan dana penelitian dari Pusat Pendidikan Kelautan dan Perikanan. Penulis juga mengucapkan terimakasih kepada ibu Pipih Suptijah dan bapak Agung Gintu atas bantuannya yang diberikan selama penelitian.

\section{DAFTAR PUSTAKA}

Angka SL, Suhartono MT. 2000. Bioteknologi Hasil Laut. Bogor (ID): PKSPL. Institut Pertanian Bogor.

[AOAC] Association of Official Analytical Chemist. 2005. Official Method of Analysis of the Association of Official Analytical of Chemist. Virgin (US): The Association of Analytical Chemist, Inc.

Ariesta, A. 2007. Karateristik mutu dan kelarutan kitosan dari ampas silase kepala udang windu (Penaeus monodon). [Skripsi]. Bogor (ID): Institut Pertanian Bogor.

[BSN] Badan Standardisasi Nasional. 2006. Penentuan kadar abu pada produk perikanan. SNI-01-2354.1-2006. Jakarta (ID): Badan Standardisasi Nasional.

[BSN] Badan Standardisasi Nasional. 2006. Penentuan kadar air pada produk perikanan. SNI-01-2354.2-2006. Jakarta (ID): Badan Standardisasi Nasional.

Bagheri Khoulenjani S, Taghizadeh S, Mirzadeh H. 2009. An investigation on the short term biodegradability of chitosan with various molecular weights and degrees of deacetylation. Carbohydrate Polymers. 78(2009): 773-778.

Belangi, I. 2018. Produksi dan karateristik kitosan larut air dengan metode hidrolisis asam. [Skripsi]. Bogor (ID): Institut Pertanian Bogor.

Cahyono, E. 2015. Produksi glukosamin dengan metode hidrolisis bertekanan sebagai bahan penunjang kesehatan sendi. [Tesis]. Bogor (ID): Institut Pertanian Bogor.

Chamidah A, Widiyanti $\mathrm{CH}$, Fabiyani NN. 2016. Pemanfaatan chitosan larut air sebagai antiseptik hand sanitizer. Jurnal Perikanan Universitas Gadjah Mada. 21(1): 9-16
[EFSA] European Food Safety Authority. 2010. Scientific opinion on the safety of chitin-glucan as a novel food ingredient. European Food Safety Authority. 8(7): 1-17.

Fadli A, Drastinawati, Alexander O, Huda F. 2015. Pengaruh rasio massa kitin/naoh dan waktu reaksi terhadap karakteristik kitosan yang disintesis dari limbah industri udang kering. Jurnal Sains Materi Indonesia. 18(2): 61-67.

Fawzya YN, Rina N, Singgih W. 2008. Pengaruh deasetilasi dan alkalinasi terhadap karakteristik karboksimetil kitosan. Jurnal Perikanan Universitas Gadjah Mada. 10(1): 64-75.

Gintu AR, Soetjipto H, Cahyanti MN. 2017. Karakterisasi dan sifat fisikokimia kitosan dari kulit udang. Seminar Nasional Kimia dan Pendidikan Kimia IX (SN-KPK IX).

Hong H, No K, Meyers SP, Lee KS. 1989. Isolation and characterization of chitin from crawfish shell waste. Journal of Agricultural and Food Chemistry. 37(3): 575-579.

Lalenoh BA, Cahyono E. 2018. Karakterisasi kitosan dari limbah rajungan (Portunus pelagicus). Jurnal Ilmiah Tindalung. 4(1): 30-33.

Putra MMP, Putra P, Husni A. 2013. Pengaruh suhu eterifikasi pada proses pembuatan karboksil metil kitosan terhadap sifat kelarutannya. Seminar Nasional Masyarakat Pengolahan Hasil Perikanan Indonesia $V$.

Nadia LMH, Huli LO, Nadia LAR. 2018. Pembuatan dan karakterisasi kitosan dari cangkang rajungan (Portunus pelagicus) asal Sulawesi Tenggara. Jurnal Fish Protech. 1(2): 77-84.

Rahayu LH, Purnavita S. 2007. Optimasi pembuatan kitosan dari kitin limbah cangkang rajungan (Portunus pelagicus) untuk adsorben ion logam merkuri. Reaktor. 11(1): 45-49.

Rahman, M A. 2012. Kitosan sebagai bahan antibakteri alternatif dalam formulasi gel pembersih tangan (hand sanitizer). [Skripsi]. Bogor (ID): Institut Pertanian Bogor.

Rochima E. 2007. Karateristik kitin dan 
kitosan asal limbah rajungan cirebon. Buletin Teknologi Hasil Perikanan. X(1): 9-22.

Rochima E. 2014. Study of utilization of crabs processing wastes and its application for chitosan-based healthy drink. Jurnal Akuatika. 5(1): 71-82.

Rohyami Y, Istiningrum RB. 2013. Preparation of chitin, study of physicochemical properties and biopesticide activities. Eksakta Journal of Sciences and Data Analysis. 13(2): 49-55.

Setha B, Rumata F, Silaban BB. 2019. Karakteristik kitosan dari kulit udang vaname dengan menggunakan suhu dan waktu yang berbeda dalam proses deasetilasi. Jurnal Pengolahan Hasil Perikanan Indonesia. 22(3): 498-507.

Sofia I, Murdiningsih H, Yanti N. 2016. Pembuatan dan kajian sifar-sifat fisikokimia, mekanikal, dan fungsional edible film dari kitosan udang windu. Jurnal Bahan Alam Terbarukan. 5(2): 5460.

Sudianto, Suseno SH, Suptijah P. 2020. Optimasi produksi kitosan larut air menggunakan metode hidrolisis bertekanan. Jurnal Pengolahan Hasil Perikanan Indonesia. 23(3): 441-446.

Suptijah P, Salamah E, Sumaryanto H, Purwaningsih S, Santoso J. 1992. Pengaruh berbagai isolasi khitin kulit udang terhadap mutunya. Laporan Penelitian Jurusan
Teknologi Hasil Perikanan. Bogor (ID): Institut Pertanian Bogor.

Suptijah P. 2006. Deskripsi karakterisasi fungsional dan aplikasi kitin dan kitosan. Di Dalam Prosiding Seminar Nasional Kitin Kitosan. Bogor (ID): Institut Pertanian Bogor.

Tanasale MFJDP, Telussa I, Sekewael SJ, Kakerissa L. 2016. Extraction and characterization of chitosan from windu shrimp shell (Penaeus monodon) and depolymerization chitosan process with hydrogen peroxide based on heating temperature variations. Indonesian Journal of Chemical Research. 3(2): 308316.

Walke S, Srivastava G, Nikalje M, Doshi J, Kumar R, Ravetkar S, Doshi P. 2014. Physicochemical and functional characterization of chitosan prepared from shrimp shells and investigation of its antibacterial, antioxidant and tetanus toxoid entrapment efficiency. International Journal of Pharmaceutical Sciences Review and Research. 26(2): 215225.

Yusharani MS, Stenley, Harmami, Ulfin I, Ni'mah YL. 2019. Synthesis of watersoluble chitosan from squid pens waste as raw material for capsule shell: temperature deacetylation and reaction time. IOP Conf. Series: Materials Science and Engineering 509 (2019) 012070 